\title{
堆肥化乾燥污泥炭化時の窒素および硫黄成分の挙動
}

\author{
須網 暁*1, 小林 信介*2, 浜辺 久*3, 澤井 正和 ${ }^{* 4}$, 板谷 義紀 ${ }^{* 2}$
}

\section{Behavior of nitrogen and sulfur in the char produced from bio-dried sludge}

\author{
Akira SUAMI*1, Nobusuke KOBAYASHI*2, Hisashi HAMABE ${ }^{* 3}$, \\ Masakazu SAWAI*4 and Yoshinori ITAYA*2

\begin{abstract}
${ }^{* 1}$ Department of Environmental and Renewable Energy System, Gifu University, 1-1 Yanagido, Gifu-shi, Gifu 501-1193, Japan ${ }^{* 2}$ Department of Mechanical Engineering, Gifu University, 1-1 Yanagido, Gifu-shi, Gifu 501-1193, Japan ${ }^{{ }_{3}}$ OBU UNITY, Co., Ltd., Komaba Kitazaki-cho, Obu-shi, Aichi 474-0001, Japan ${ }^{*}$ Techno Plan, Co., Ltd., Koyotyonaka, Higashinada-ku, Kobe-shi, Hyogo 658-0032, Japan
\end{abstract}

\section{Received 29 August 2014}

\begin{abstract}
In order to evaluate nitrogen and sulfur behavior during carbonization, carbonization experiment with bio-dried sludge was conducted in a horizontal lab-scale reactor and rotary kiln. Bio-dried sludge dried by using fermentation was used as the carbonization material. Carbonization temperature was changed from 573 to $1173 \mathrm{~K}$, and the effect of steam introduction on the elements behavior during the carbonization process was revealed. Nitrogen in the bio-dried sludge decomposed linearly with rising treatment temperature, and more than $90 \%$ of nitrogen decomposed at the $1173 \mathrm{~K}$ temperature. Sulfur in bio-dried sludge decreased slowly with increasing treatment temperature, but the decreasing ratio was insignificant against the carbonization temperature. Around $70 \%$ of sulfur remained in the char after the carbonization at $1173 \mathrm{~K}$. Sulfur behavior was changed when the steam was introduced during the carbonization. Sulfur content in the char was decreased significantly.
\end{abstract}

Key words : Sludge treatment, Carbonization, Nitrogen, Sulfur, Material balance

\section{1. 緒言}

下水道の整備が進むにつれ年々莫大な污泥が発生していることから（鈴木他，2014），（鳥井他，2013）, 污泥の焼 却による污泥処理量の増大が予想されている. 従来の污泥処理では発生した污泥は濃縮・脱水されているものの, 脱 水後の污泥の含水率は 8 割以上であることから焼却処理前には乾燥処理を施さなくてはならず，脱水污泥の乾燥や燒 却処理のために大量のエネルギーが消費されている. その一方で有機物を含む污泥は供給量が安定しているバイオマ ス資源としても近年位置づけられるようになり，污泥のコンポスト利用（高橋他，2006）や発酵によるメタンガス製 造，炭化処理による固体然料化などの利用技術が開発され，すでに実用化もされている. 中でも污泥の炭化処理は污 泥をエネルギーとして利用することが可能なだけでなく, 得られる污泥炭化物は多孔質構造を形成していることから 吸着剤としての利用も期待されている（馬場，藤田，2002），(御友他，2003）。しかしながら，污泥から炭化物を得 る際にも，脱水污泥の脱水や乾燥においてエネルギーを消費しているため污泥炭化におけるエネルギー消費量の削減 が望まれていた，そのため，著者らは図 1 に示すような堆肥化と炭化を組み合わせた新たな污泥処理システムを提案

No. 14-00439 [DOI: 10.1299/transjsme.14-00439], J-STAGE Advance Publication date : 11 August, 2015

*1 岐阜大学大学院 工学研究科 環境エネルギーシステム専攻（テ501-1193 岐阜県岐阜市柳戸1-1）

$*_{2}$ 正員, 岐阜大学 工学部 機械工学科

*3 オオブユニティ (株)（テ474-0001 愛知県大府市北崎町駒場 88)

*4 (株) テクノプラン（テ658-0032 兵庫県神戸市東灘区向洋町中 6-9 KFM ビル 4 階)

E-mail of corresponding author: t3812003@edu.gifu-u.ac.jp 
している（板谷，2013）. 本システムは，污泥の堆肥化による乾燥と堆肥化乾燥污泥の炭化を組み合わせた污泥処理 システムであり，堆肥化時に大幅に含水率が減少するため従来のように燃料を使用することなく炭化物の製造が可能 となっている. また，得られた炭化物を脱水污泥に混合することでさらに高い乾燥効率を達成できることも明らかに している（小林他，2014）。ただし，本污泥処理システムを構築するためには堆肥化および炭化プロセスにおける物 質的，エネルギー的なバランスを把握し最適な制御を行うだけでなく，環境にも配慮したシステムの構築が必要とさ れている.

現在, 污泥の炭化に関する研究は数多く報告されており, 污泥の炭化により発生するガスやタールの挙動, 生成さ れる炭化物の細孔構造, 吸着性能や発熱量などが明らかにされつつある (大下他, 2008), (松永他, 1995), (森田他, 1997）。污泥には炭化物の原料となるカーボンだけではなく, 多量の窒素や硫黄成分が含まれているため, 炭化過程 や燃焼過程における窒素化合物および硫黄化合物の大気中への放出が危惧されている．窒素や硫黄の挙動については 石炭の燃焼において長年にわたり研究が行われており，窒素化合物や硫黄化合物の生成過程や制御方法についても明 らかにされ，その除去技術もすでに確立されている（牧野他，1994），(斉藤他，2003）。污泥炭化時の窒素挙動につ いても近年研究が進められており, 污泥中窒素成分挙動については主にアンモニアとして生成されることが報告され, 污泥中の窒素挙動は明らかになり始めている（中川，人見，2013）。しかしながら污泥中の窒素および硫黄成分の炭 化時における挙動について検討を行った報告はまだ少なく, 特に実規模装置を用いた炭化時の窒素や硫黄挙動を明ら かにした詳細な報告はほとんど見当たらない. また, 堆肥化乾燥污泥を原料とした場合の炭化時の窒素や硫黄の挙動, さらには炭化炉内の水蒸気が堆肥化乾燥污泥中の窒素および硫黄挙動に与える影響についてもほとんど明らかにされ ていない. そのため, 本研究では実規模装置に近い炭化装置を用いて堆肥化乾燥污泥を原料とする炭化実験を行い, 炭化過程における污泥中の窒素および硫黄成分の挙動について検討を行うとともに，水蒸気が污泥中の窒素および硫 黄成分に与える影響について検討を行った. 実験では, ラボスケールの反応管を用いて炭化温度および水蒸気濃度を 変化させた堆肥化乾燥污泥の炭化実験を行うとともに, ロータリーキルンの炭化装置を用いた堆肥化乾燥污泥の炭化 実験を行い，炭化時の温度が污泥中の窒素および硫黄挙動に与える影響について検討を行った.

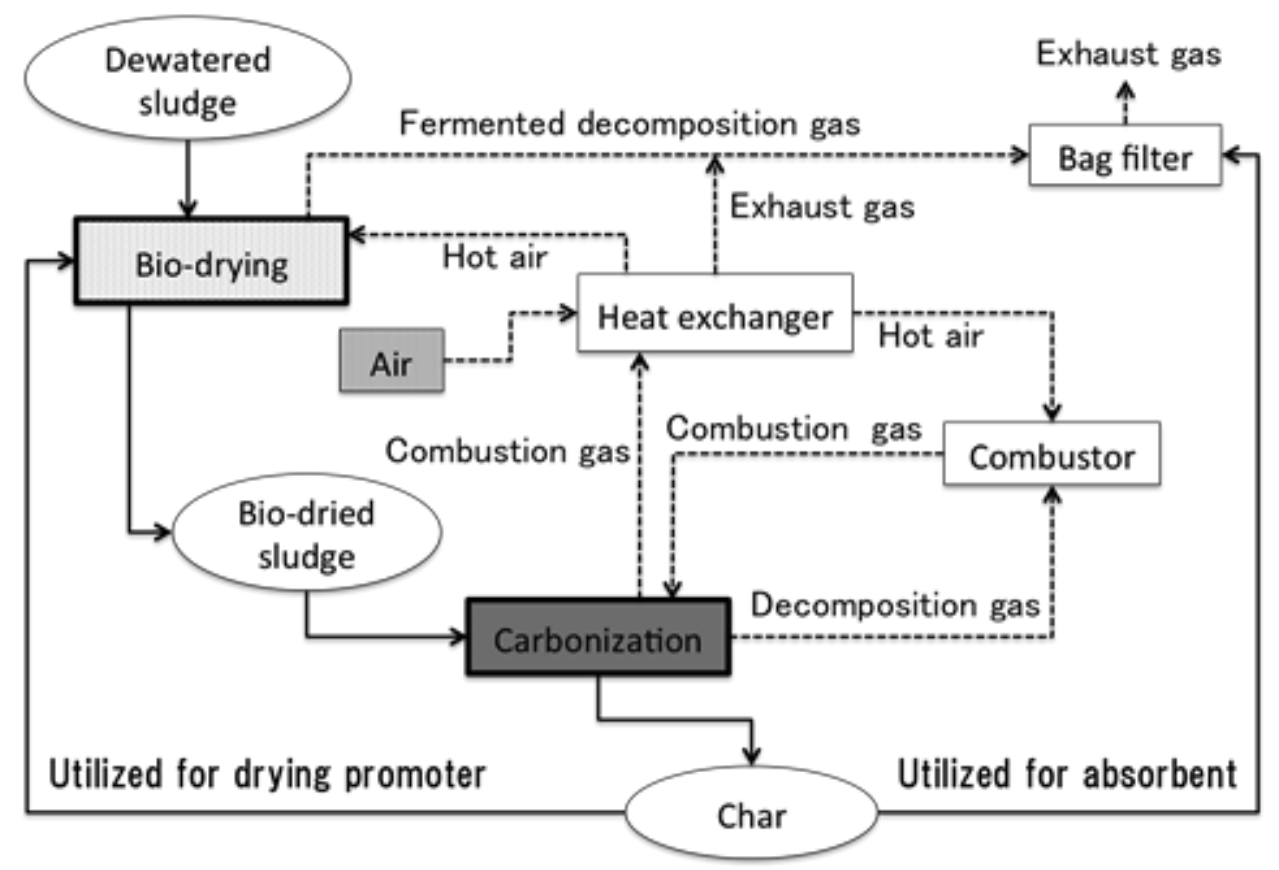

Fig.1 Combined sludge treatment

\section{2. 実験}

\section{$2 \cdot 1$ ラボスケール炭化実験}

図 2 にラボスケールの堆肥化乾燥污泥用の小型炭化実験装置を示寸 (以下，小型炭化装置). 小型炭化装置は, ガス 
流通式の炭化装置で, 反応器には内径 $55 \mathrm{~mm}$, 長さ $630 \mathrm{~mm}$ の石英ガラス管と電気炉を用いた. 反応管内の出口に はタール回収装置およびガス回収バックを設置し，生成物はすべて回収した，炭化時の流通ガスには窒素および水蒸 気を用い，反応管内のパージガスである窒素は $200 \mathrm{~mL} / \mathrm{min}$ で流通させた. 水蒸気を流通させる場合には，窒素を流 通させながらシリンジポンプを用いて水を気化器に供給することで反応管内の水蒸気濃度を $0-60 \%$ 範囲で変化 させた. 実験試料は堆肥化乾燥污泥約 $5 \mathrm{~g}$ を石英ガラスセルに高さ $10 \mathrm{~mm}$ 程度均一に充填し, 電気炉の外側の反応 管部分に設置した. 堆肥化乾燥污泥の炭化は電気炬に覆われている反応管の温度が処理温度まで到達した後, 試料セ ルをロッドで電気炉内に押し出すことにより急速昇温を行った．炭化時間は後述するロータリーキルン炭化実験の滞 留時間と同じ $30 \mathrm{~min}$, 炭化温度は $573-1173 \mathrm{~K}$ とした. 加熱による反応管内温度は試料セル直上に設置した熱電対 により制御した．試料セル直上の温度を本実験における炭化温度とした.

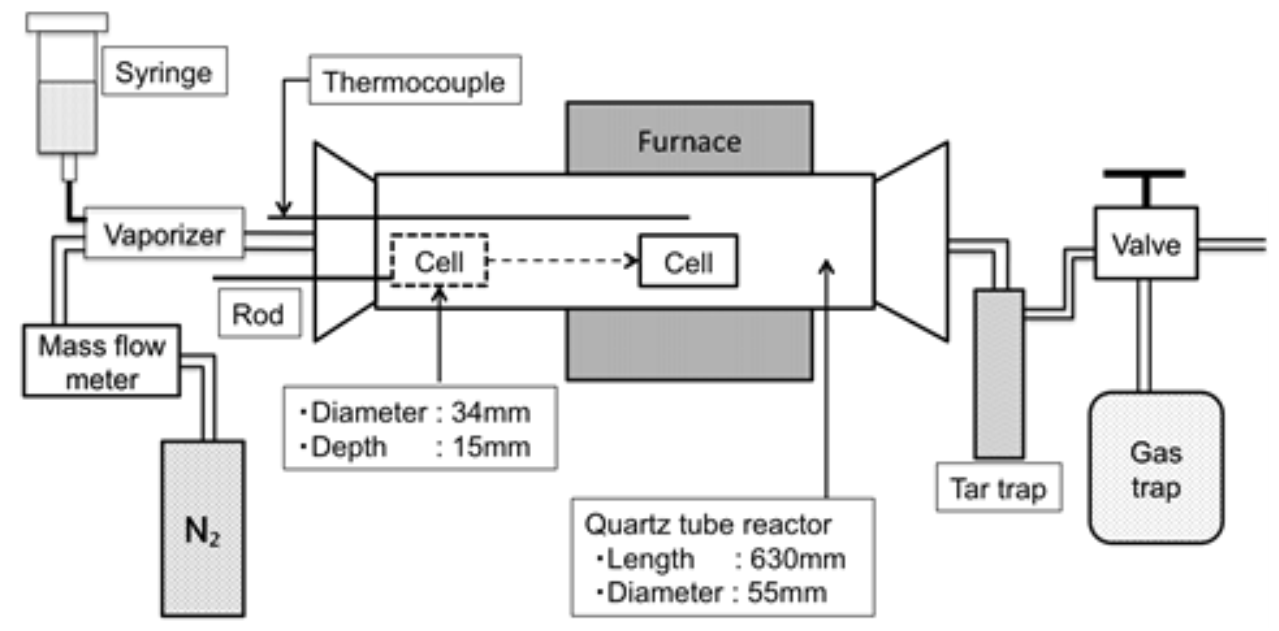

Fig.2 Lab-scale carbonization experiment unit

\section{$2 \cdot 2$ ロータリーキルン炭化実験}

実規模炭化装置として内径 $550 \mathrm{~mm}$ ，外径 $610 \mathrm{~mm}$ ，外筒長さ $3000 \mathrm{~mm}$ のロータリーキルンを用いた(以下，キル ン). 図 3 にキルンの全体図を示す. キルンは二重管となっており内筒では堆肥化乾燥污泥の炭化を行い, 外筒には堆 肥化乾燥污泥の熱分解によって発生したガスを空気と混合し, 燃焼室にて燃焼させた燃焼ガスを流通させることで試 料の間接加熱を行っている．温度測定には炉内出口に設置してある熱電対を用い，キルン内のガス雰囲気温度の測定 を行った. 内筒は出口側に向かって 1 。 の勾配がつけてあり, 試料は押し出し流れにより排出される. 投入する試料 はラボスケール実験と同じで, 2 軸式スクリューフィーダにより連続的にキルン内に供給した. 試料の投入量は $20 \mathrm{~kg} /$ $\mathrm{h}$ で一定とし, 炉内温度制御は燃焼室の空気量調節により行った. ただし, 本装置は処理量が少ないため, 助燃剤と して灯油を用いた. 堆肥化乾燥污泥の炭化中には水蒸気や熱分解ガスが発生するが，キルン内圧はキルンの試料投入 口において炉内圧が 0 になるように誘引ファンにより調整を行っている. キルン回転数は $1.5 \sim 2 \mathrm{rpm}$ とし，その場 合試料のキルン内滞留時間は約 $30 \mathrm{~min}$ であった. 処理後の炭化物は炭化炉出口より間接水冷スクリューコンベヤを 通り排出される. キルン内の温度が目的温度で安定した後, 得られた污泥炭化物 (以下, 炭化物)を分析試料とした.

\section{$2 \cdot 3$ 実験試料および評価方法}

小型炭化装置およびキルンにおける炭化実験の試料には，堆肥化乾燥污泥 (以下，乾燥污泥)を使用した．乾燥污泥 は含水率 $77 \%$ の脱水污泥に約 $30 \%$ の炭化物を加え, 4 日間の堆肥化により含水率 $30 \%$ 以下に乾燥させたものである. 乾燥污泥の JIS 分析法による工業分析值および元素分析值の結果をそれぞれ表 1,2 に示す. 乾燥污泥の揮発分は $45.3 \%$ と最も多く, 灰分は $40.5 \%$, 固定炭素は $14.2 \%$ 含んでいた. 図 4 に脱水污泥から乾燥污泥一の堆肥化発酵過 程における元素成分の乾燥ベースにおける物質収支を示しておく. 堆肥化過程において脱水污泥中の炭素, 水素, 窒 素, 酸素成分がそれぞれ 60 \%程度減少している. これは堆肥化の進行により脱水污泥の有機成分が水蒸気, メタン, 二酸化炭素, アンモニア, 窒素などのガスとして分解されたためである（中村他，2005）。一方, 硫黄成分は, 低下 しておらず，逆に増加していた。これは堆肥化過程においては分解が進んでおらず，污泥内に残留したことおよび炭 化物を乾燥污泥に加えていることが原因である. 
実験では炭化物の評価を行うため, それぞれの炭化装置において炭化物を製造した後, 炭化物の収率を計るととも に炭化物に含まれる炭素, 水素, 窒素, 硫黄および灰の割合を測定した，炭化物収率の定義を式（1）に示す.

$$
\text { Yield }=W_{i d . b} / W_{i_{0} d . b}
$$

ここで, $W_{i d . b}$ は炭化後の重量, $W_{i_{0}} d . b$ は試料の乾燥べースの初期重量である. 元素分析には, 元素分析装置 (DKSH, vario EL cube）を用いた．ただし，酸素成分は全体重量より CHNS および灰分を差し引いた值とした．灰分割合に ついては大気中にて $1088 \mathrm{~K}$ の温度で灰化させた時の重量より算出した. 得られた炭化物は吸着剤としての性能を評 価するため BET 比表面積の測定も行った. BET 比表面積の測定には, 全自動ガス吸着量測定装置 (AUTOSORB-1) を用いた。

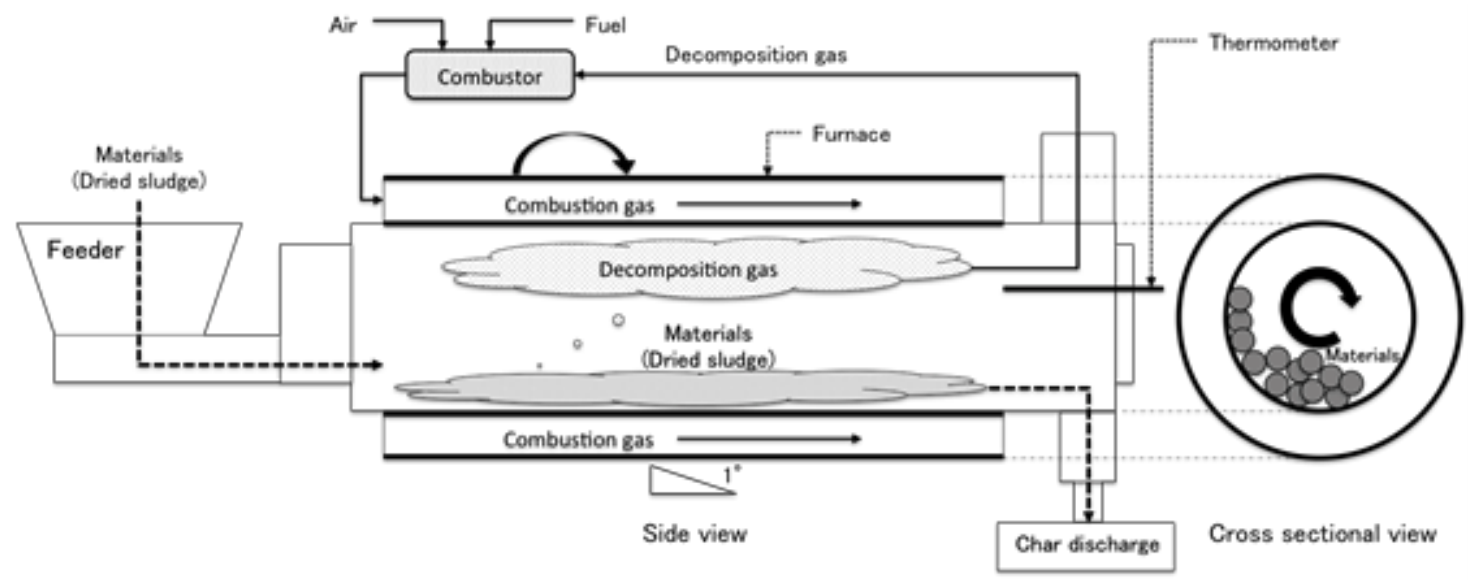

Fig.3 Outline of rotary kiln

Table 1 Proximate analysis of dried sludge

\begin{tabular}{c|c|c|c|c}
\hline Component & Moisture (w. b.) & Volatile matter (d. b.) & Fixed carbon (d. b.) & Ash (d. b.) \\
\hline Composition [wt\%] & 18.8 & 45.3 & 14.2 & 40.5 \\
\hline
\end{tabular}

Table 2 Ultimate analysis of dried sludge

\begin{tabular}{c|c|c|c|c|c}
\hline Element & $\mathrm{N}$ & $\mathrm{C}$ & $\mathrm{H}$ & $\mathrm{S}$ & $\mathrm{O}$ \\
\hline Composition [wt\%] (Dry ash free) & 6.9 & 45.0 & 6.4 & 2.9 & 38.8 \\
\hline
\end{tabular}

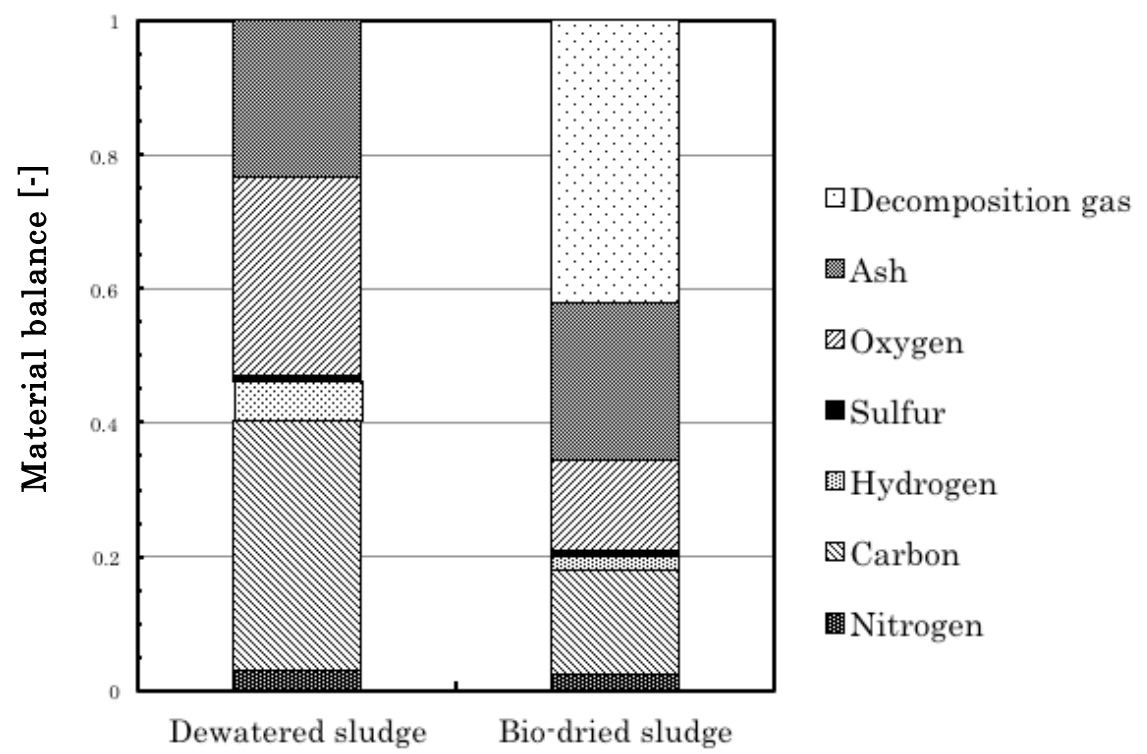

Fig.4 Material balance during composting 


\section{3. 結果と考察}

\section{$3 \cdot 1$ ラボスケール炭化実験}

小型炭化装置で得られた炭化物の収率を図 5 に示寸. 炭化物の収率は炭化温度を上げるとともに減少した. また, 同温度において水蒸気雾囲気下で炭化した場合には窒素雾囲気下で製造した炭化物に比べ，収率が減少する傾向とな った．炭化する試料のサンプリングにより炭化物収率には若干のバラツキが生じており，窒素雾囲気下で得られた炭 化物収率の標準偏差は $0.006-0.02$ 程度であった. 低温の炭化条件における収率のバラツキは比較的小さいものの, 高温の炭化条件では収率のバラツキが大きくなる傾向が見られた. $673-973 \mathrm{~K}$ では水蒸気による収率の低下は少な いものの, $1073 \mathrm{~K}$ 以上では水蒸気と炭素のガス化反応により収率の低下が大きくなった. $973 \mathrm{~K}$ 以下の水蒸気濃度 変化による収率の差は小さいものの, $1073 \mathrm{~K}$ では水蒸気濃度変化による収率の差が見られ，今回の実験において水 蒸気濃度が最も高い $60 \%$ の場合が最も低い収率を示した。

窒素雰囲気下で乾燥污泥を炭化した時の物質収支を図 6 に示寸. 図は乾燥污泥を炭化して得られたチャー, タール， 水，ガスの割合を示したものである．炭化時に生成するタールと水分は同時に採取しているため，それらは合計とし て表示し，チャー中に含まれる灰分割合も合わせて示した．乾燥污泥には灰成分が 35 \%程度含まれており，単位污泥 中の灰重量は炭化温度によりほとんど变化しないため $1173 \mathrm{~K}$ での炭化においては炭化後のチャー $1 \mathrm{~g}$ 当たりには 70 \%程度の灰成分が含まれている．そのため $1173 \mathrm{~K}$ の場合に得られる炭化物の割合は初期污泥のわずか $20 \%$ に留 まる. その一方で，熱分解により生成される水分，タールの割合が多くなり， $1173 \mathrm{~K}$ では試料の約 $30 \%$ 以上がガス 成分に転化していた.

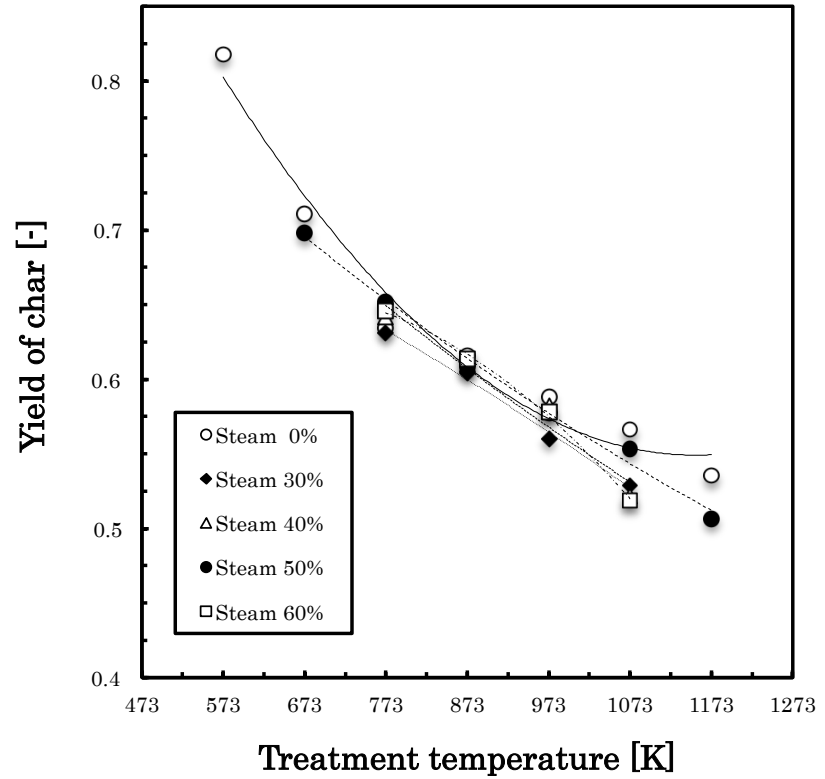

Fig.5 Yield of char carbonized in lab-scale

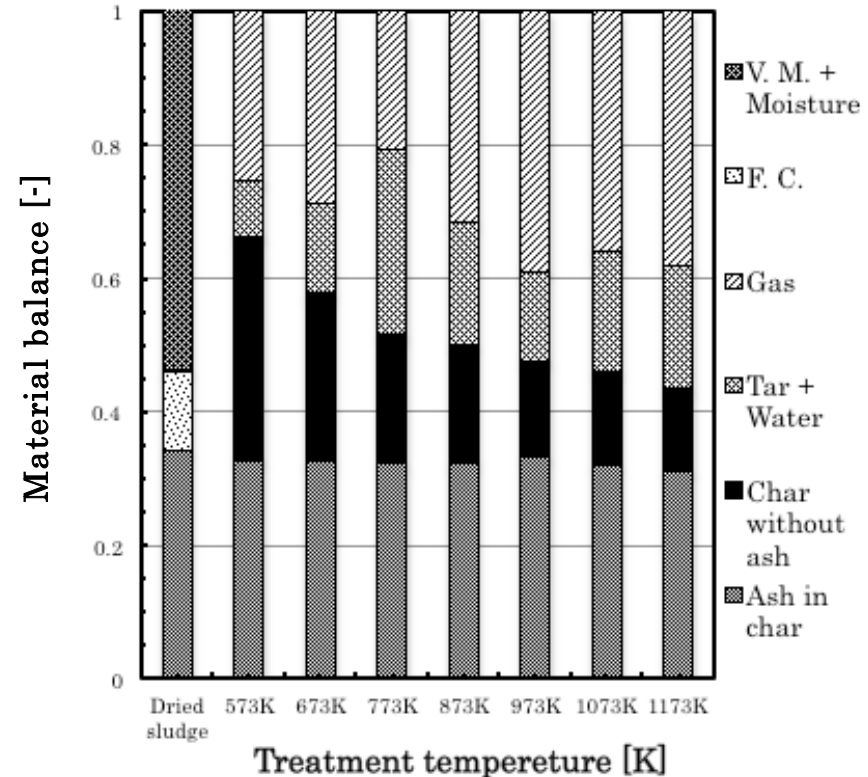

Fig.6 Material balance during carbonization in lab-scale

図 7 - 10 に炭化温度および水蒸気濃度が炭化物中の各元素成分収率に与える影響について示す. 図 $7-10$ はそれ ぞれ炭素, 水素, 窒素, 硫黄成分の収率である. ここでの収率は各元素の炭化前後の重量割合と定義している. 炭化 物中の各成分の収率は, 炭化温度を上げるとともに減少するものの各元素成分により減少傾向は異なっていた. 炭素 成分の収率は炭化温度 $773 \mathrm{~K}$ までは線形的に減少するものの, $873 \mathrm{~K}$ 以上では減少する割合は小さくなり, 窒素雾囲

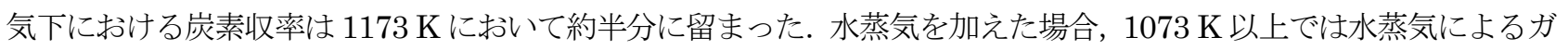
ス化反応により炭素収率は低下し, 水蒸気の有無により約 $10 \%$ 差が見られた. $973 \mathrm{~K}$ 以下では水蒸気濃度変化に対

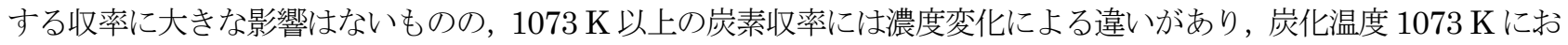
いて水蒸気濃度 $60 \%$ で最も大きな収率の低下が見られた. 水素収率は比較的低温の炭化条件においても急激に減少す るが炭化温度とともに収率の減少割合は小さくなり，973 K 以上の炭化温度ではほぼ $0 \%$ となった．水蒸気を加える ことにより $773 \mathrm{~K}$ 以上では試料中の水素分の減少は若干抑制されるものの $973 \mathrm{~K}$ 以上ではほぼ $0 \%$ 
率は炭化温度が高くなるにつれ線形的に減少し，同じ炭化温度で水蒸気を加えた場合，窒素収率はさらに低下した。 特に高温になるとともに水蒸気の影響は顕著であり，水蒸気の有無により収率に差が生じていた．しかし，窒素およ び水素の収率においては, 水蒸気添加や水蒸気濃度による変化はわずか数 \%であることから両元素への水蒸気の有無 および水蒸気濃度変化の影響は小さいと考えられる. 硫黄収率は窒素雾囲気下において $873 \mathrm{~K}$ まで急激に減少し, 973 $\mathrm{K}$ まで $70 \%$ の一定值を維持するが, $1073 \mathrm{~K}$ 以上で収率は約 $75 \%$ まで増大した. これは $1073 \mathrm{~K}$ 以上の高温では硫黄 成分は灰成分中のカルシウムなどに固定化されるためだと考えられる（林他，1996）. 水蒸気を加えた場合では処理 温度を上げることで硫黄収率は大きく減少した. 特に $973 \mathrm{~K}$ 以上の収率は急激に減少しており, $1073 \mathrm{~K}$ の水蒸気濃 度 60 \%において約 40 \%まで低下した．これは炭化処理中に水蒸気を含むことにより，まず式 (2) に示すように水 蒸気と污泥中炭素が反応寸ることで水素と一酸化炭素が生成される（草川，1948）。次に式（3），（4）に示すよう にそれら 2 成分が污泥中硫黄と反応寸ることで硫化水素および硫化カルボニウムが生成され, 活泥中硫黄の分解が進 行寸る可能性が考えられる (草川, 1948), (小松原他, 1985). 水蒸気を含む炭化処理において污泥中硫黄はカルシ ウムに固定化されるだけでなく，ガス成分にも転化されるため，炭化物中の硫黄収率が減少したことが考えられる. そのため, 窒素雾囲気下で得られた炭化物と水蒸気雰囲気下で得られた炭化物の X 線回折分析を行った. 1173K の 炭化時に得られる炭化物において水蒸気を含まない場合, 硫黄は污泥中のカルシウムに固定化されていることが考え られるため, X 線回折パターンは硫化カルシウムの有無について着目した. 図 11 に炭化物の X 線回折パターンを示 す．污泥は複数の化合物を含んでいるため，数多くのピークが見られるが，窒素雾囲気下で得られた炭化物には小さ くではあるが硫化カルシウムのピークが見られる. 一方, 水蒸気雰囲気下で得られた炭化物には硫化カルシウムの強 度が小さくなる部分やピークが見られない部分がある. 特に水蒸気雰囲気下で得られた炭化物の $2 \theta=75 \operatorname{deg}$ 付近に は硫化カルシウムのピークが見られないため, X 線回折パターンの比較から水蒸気により污泥中硫黄は分解される傾 向があり，ガス成分に転化したことが考えられる．乾燥污泥を炭化処理して得られる炭化物は，炭素と灰分の割合が 大きいが，污泥中硫黄も分解されず炭化物中に残留するものの水蒸気の添加により硫黄挙動は大きく異なることがわ かった.

$$
\begin{aligned}
& \mathrm{H}_{2} \mathrm{O}+\mathrm{C} \rightarrow \mathrm{CO}+\mathrm{H}_{2} \\
& \mathrm{H}_{2}+\mathrm{S} \rightarrow \mathrm{H}_{2} \mathrm{~S} \\
& \mathrm{CO}+\mathrm{S} \rightarrow \mathrm{COS}
\end{aligned}
$$

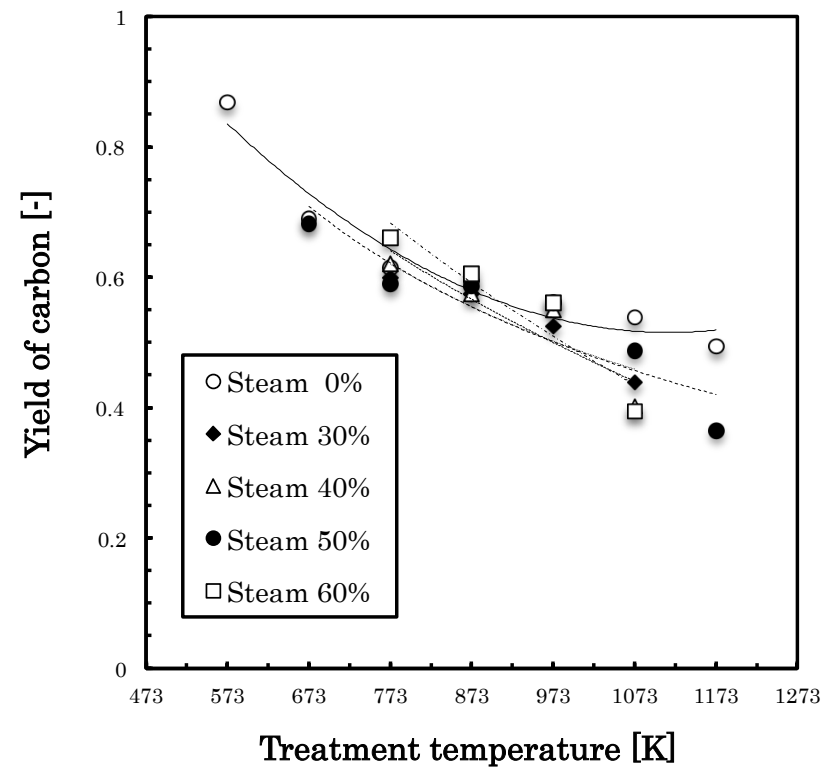

Fig.7 Yield of carbon in char produced in lab

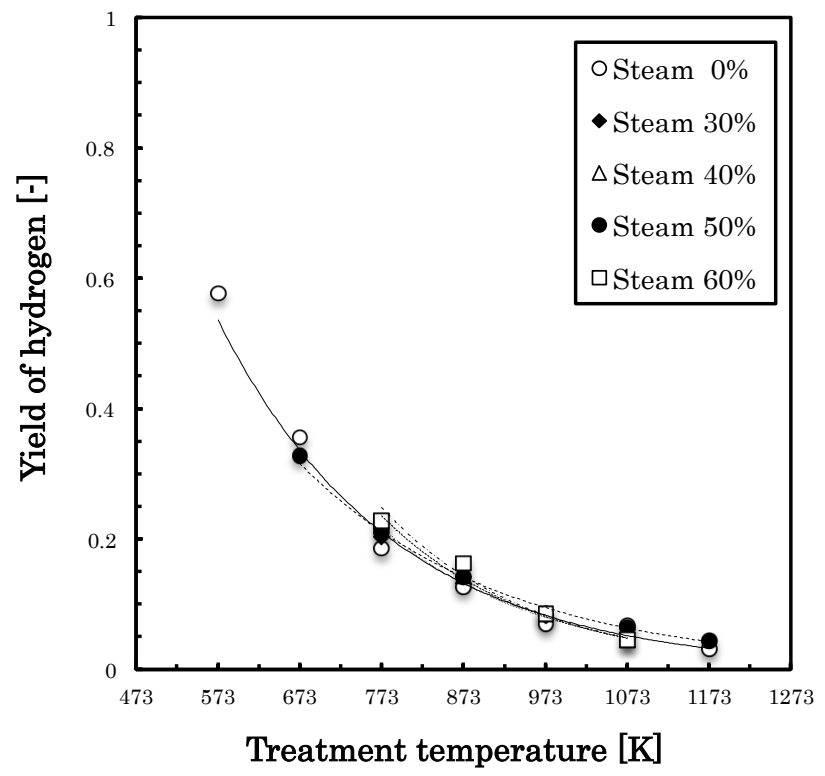

Fig.8 Yield of hydrogen in char produced in lab 


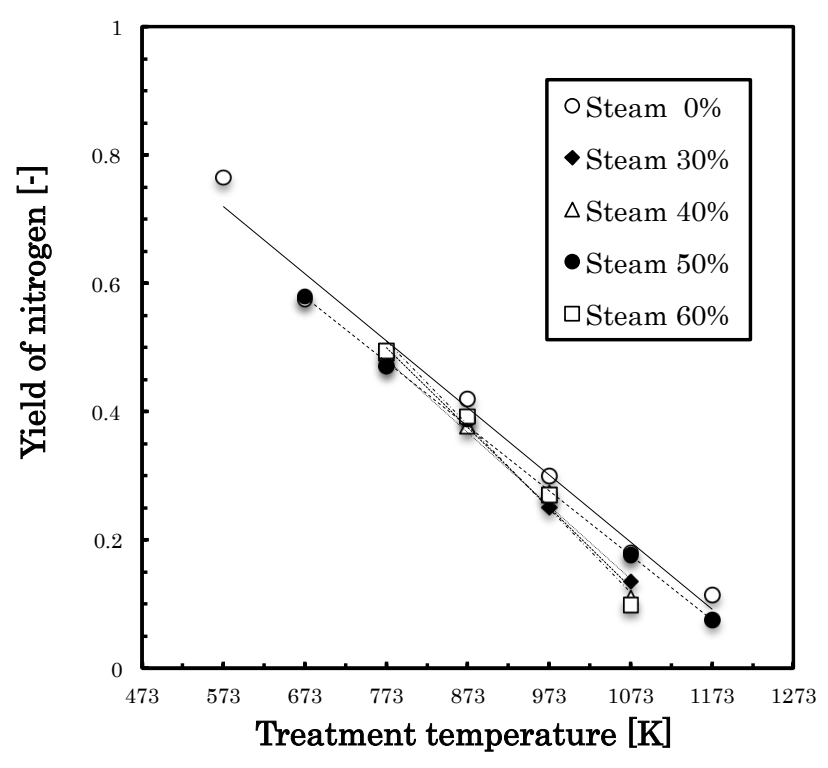

Fig.9 Yield of nitrogen in char produced in lab

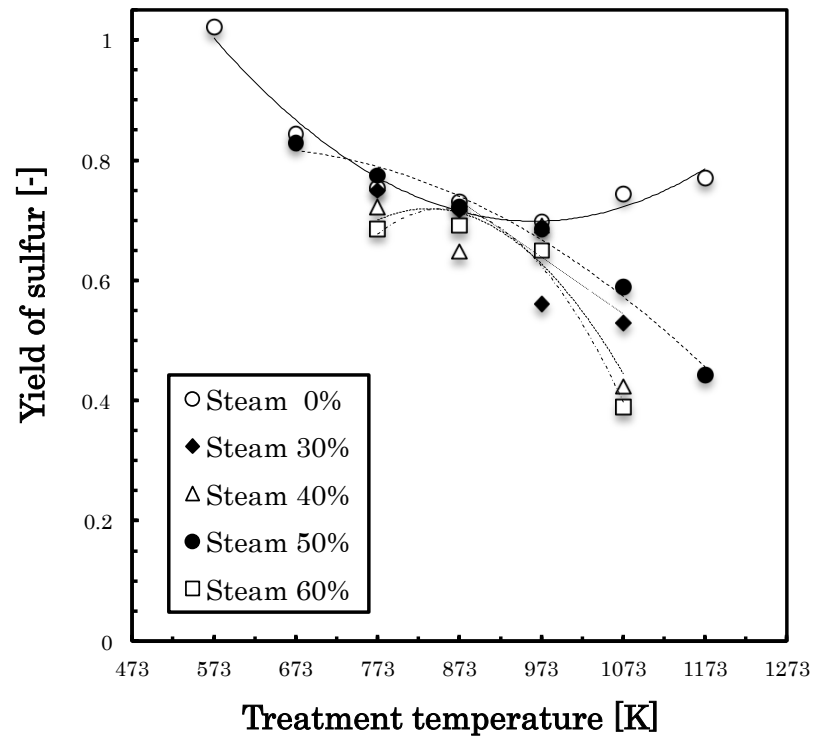

Fig.10 Yield of sulfur in char produced in lab

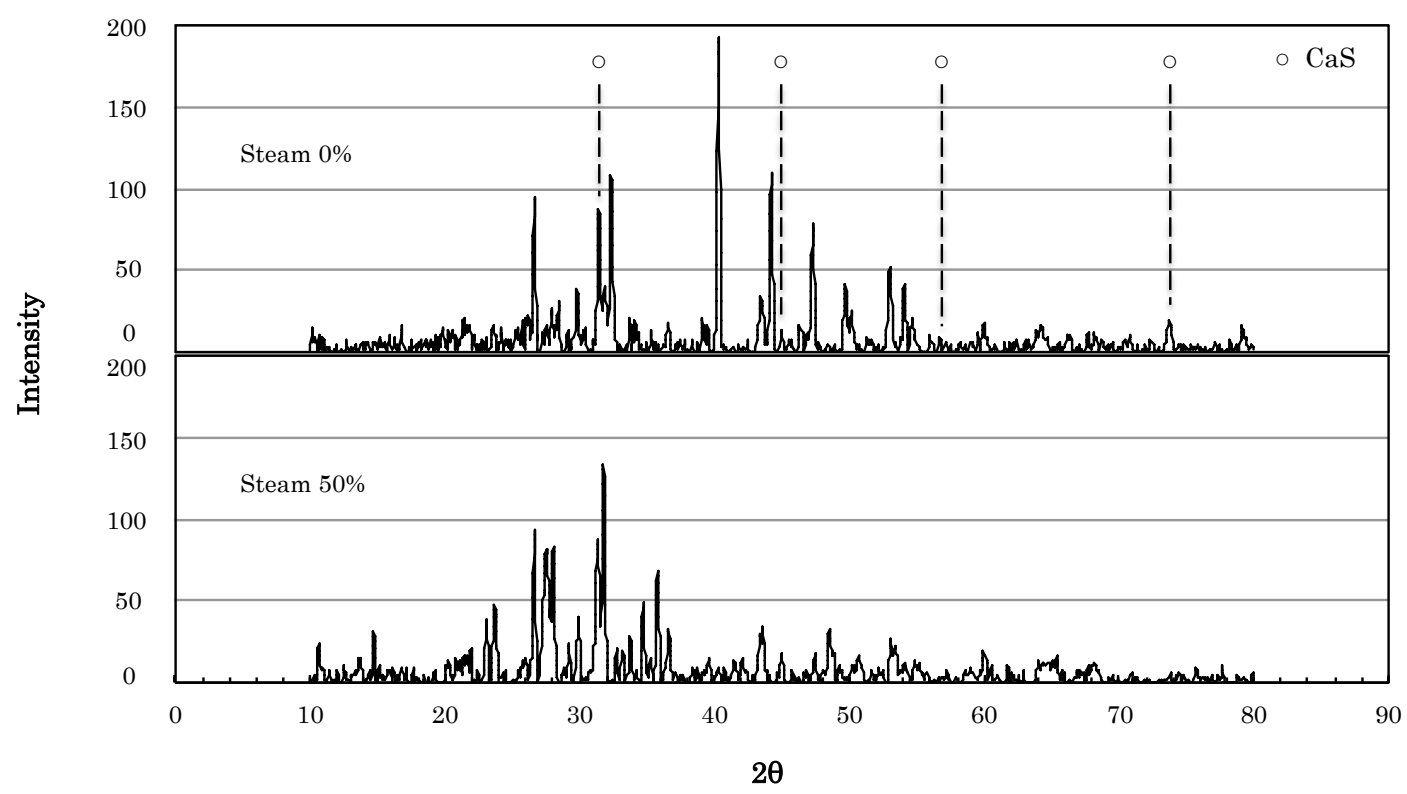

Fig. 11 X-ray spectrum of char

図 12 に異なる条件下で製造した炭化物の BET 比表面積を示す．窒素雾囲気下で得られた炭化物の BET 比表面積 は炭化温度 $873 \mathrm{~K}$ までは増加する割合が低いものの，973 K 以上では増加する割合が大きくなり，炭化温度 $1173 \mathrm{~K}$ では約 $122.1 \mathrm{~m}^{2} / \mathrm{g}$ の BET 比表面積を有する炭化物が得られた．水蒸気を加えて炭化した場合，同温度における窒素 雰囲気下の炭化に比べ, BET 比表面積は増加した. $873 \mathrm{~K}$ 以下では水蒸気とのガス化反応の影響による BET 比表面 積の増加は低いものの，973 K からガス化反応の影響により賦活効果が現れ始め，窒素雾囲気下で製造した炭化物に 比べBET 比表面積の増加が大きくなった. 水蒸気ガス化反応において, 図 5 のチャ一収率および図 7 の炭素収率で は大幅な低下は見られないものの, BET 比表面積が増加していることからチャ一内の細孔が発達し始めていることが 考えられる. 特に水蒸気濃度を $30-40 \%$ の割合で加えた場合にはガス化反応のよる BET 比表面積の大幅な増加が 見られた. 一方, $60 \%$ の場合では BET 比表面積の増加が低いことから, 水蒸気濃度が高い場合, 水蒸気による污泥 中炭素への過剩な反応により細孔が大きく発達してしまうため, BET 比表面積の増加量が小さいものと考えられる. 
また, 水蒸気を加えて炭化した場合, $1073 \mathrm{~K}$ 以上では図 10 より硫黄収率が大幅に低下寸ることから, 炭化物の BET 比表面積の増加には硫黄の分解も影響しているものと考えられる.

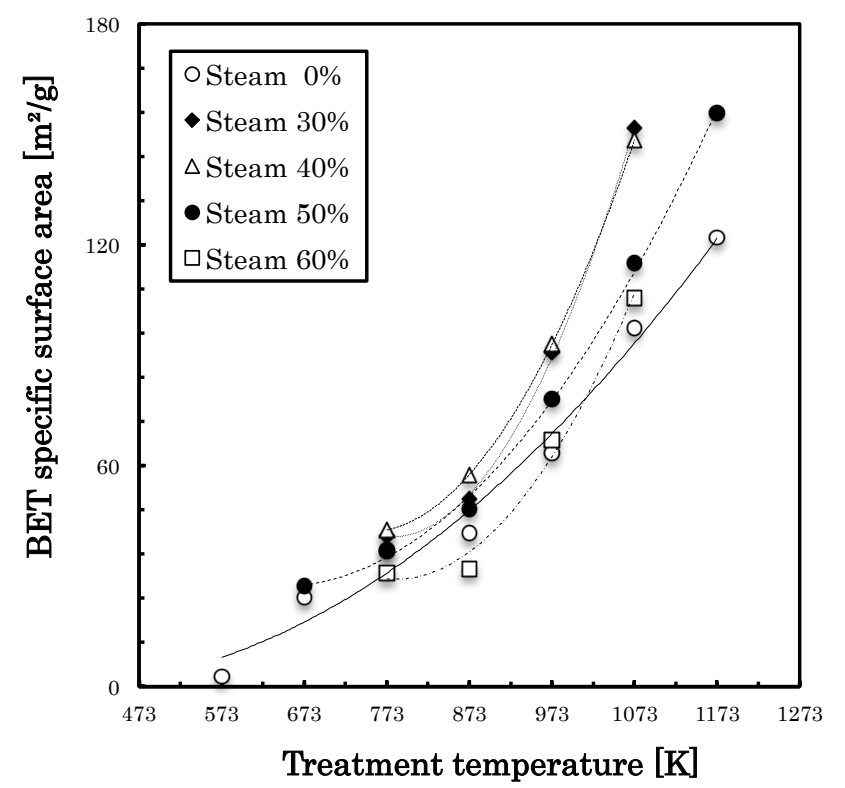

Fig.12 BET specific surface area of char carbonized in lab-scale

\section{$3 \cdot 2$ ロータリーキルン炭化実験}

キルンを用いた乾燥污泥の炭化実験において得られた炭化物の収率を図 13 に示す．収率は得られた炭化物の灰分 重量が炭化前後で一定であるとして算出を行った. 小型炭化装置と同様にキルンにおいても炭化温度を上げることで, 得られる炭化物の収率は低下寸る傾向を示した. キルンで得られる炭化物の収率にはバラツキが見られるものの, 800 $\mathrm{K}$ までの炭化によって得られる炭化物の収率は 50 - 60 \%となった. 小型炭化装置によって得られた炭化物とキルン によって得られた炭化物の収率は炭化温度 $600-800 \mathrm{~K}$ までの範囲において 1 割程度減少しており,減少傾向は類似 していた. 炭化温度 600 - $800 \mathrm{~K}$ のキルンによって得られた炭化物収率と小型炭化装置において得られた炭化物の収 率が同じになる炭化温度は $773-973 \mathrm{~K}$ であり，150-200 K 程度の差が見られた.

図 14 - 15 に炭化により得られる炭化物中の炭素，水素および窒素，硫黄の収率を示寸．ここでの収率も各元素の 炭化前後の重量割合と定義している，炭素収率は炭化温度 $700 \mathrm{~K}$ 程度までは減少するものの，700 K 以降では大きな 低下は見られず半分程度が残留していた．小型炭化実験の結果より $1073 \mathrm{~K}$ 以上で水蒸気の影響が大きくなり炭素収 率が低下したため, キルンの炭化温度 $600-800 \mathrm{~K}$ では水蒸気による炭素収率への影響は小さいと考えられる. 水素 収率は炭化温度を上げるほど急激に低下し, 炭化物中への残留は少なくなり小型炭化装置と同様の傾向を示していた. 窒素収率はバラツキが少なく炭化温度が上がるとともに線形的に低下し，小型炭化装置で得られた炭化物中の炭化温 度に対する収率の傾きとおおよそ一致していた。 しかしながら，小型炭化装置とキルンでは同じ炭化温度で得られる 窒素収率には $10 \%$ 程度の差が見られ，キルンで炭化を行った場合の方が収率は小さくなっていた. 硫黄收率は炭素収 率と同様に $700 \mathrm{~K}$ 程度まで低下していくものの，4 割ほどしか分解が進まず炭化物中に残留する結果となった．小型 炭化装置で水蒸気を加えた場合，973 K から急激に収率は低下寸るものの，873 K まで収率は一定を維持していたた め，キルンの炭化温度 $600-800 \mathrm{~K}$ の硫黄収率にも水蒸気の影響は小さく, 減少傾向も小型炭化装置の結果と類似し ていた．また，キルンで得られた硫黄収率のバラツキは大きいものの，小型炭化装置とキルンの硫黄収率には同じ炭 化温度において差が見られた。 キルンで炭化した方が低い温度で窒素収率と硫黄収率は低下しており，炭化物中の窒 素収率が同じ場合，あるいは硫黄収率が同じ場合の炭化温度は $150-200 \mathrm{~K}$ 程度の違いが見られた.

図 16 にキルンで製造した炭化物の BET 比表面積を示す. 小型炭化装置で得られた炭化物と同様に炭化温度を上げ ることで炭化物の BET 比表面積は大きくなる傾向が見られた. キルンを用いた実験では炭化物製造量に対してサン プリング量は圧倒的に少なく, 測定する試料にバラツキがあることから BET 比表面積の值にはバラツキが見られた. 
キルンによる炭化においては，乾燥污泥の熱分解の他に水蒸気や二酸化炭素とのガス化反応も同時に起きていること から, 比較的低温の炭化条件においても BET 比表面積は $20 \mathrm{~m}^{2} / \mathrm{g}$ 以上であった. $773 \mathrm{~K}$ 以上の炭化温度では BET 比表面積は $70 \mathrm{~m}^{2} / \mathrm{g}$ 程度有した炭化物が得られており, 小型炭化装置よりも大きな BET 比表面積の炭化物が得られ た. それぞれの実験で製造した炭化物の BET 比表面積を比較すると炭化物の BET 比表面積にも差が見られ, 同じ比 表面積における炭化温度には 150 - $200 \mathrm{~K}$ の差があり, キルンで炭化を行った場合の方が低温で高い BET 比表面積 が得られた．キルンの温度はキルン内のガス雾囲気を示しており炭化されている試料の温度ではない可能性が高く， また炭化物の収率，窒素および硫黄収率さらには BET 比表面積の結果よりキルン炉壁面またはキルン内における最 高到達温度は表示している温度より $150-200 \mathrm{~K}$ 高い温度で炭化が行われたことが考えられる. 小型炭化装置とキル ンの結果を比較することによりキルンでの実際の試料の炭化温度が把握できる可能性が示され，キルンで製造される 炭化物には小型炭化装置で得られた炭化物の知見が反映できることがわかった.

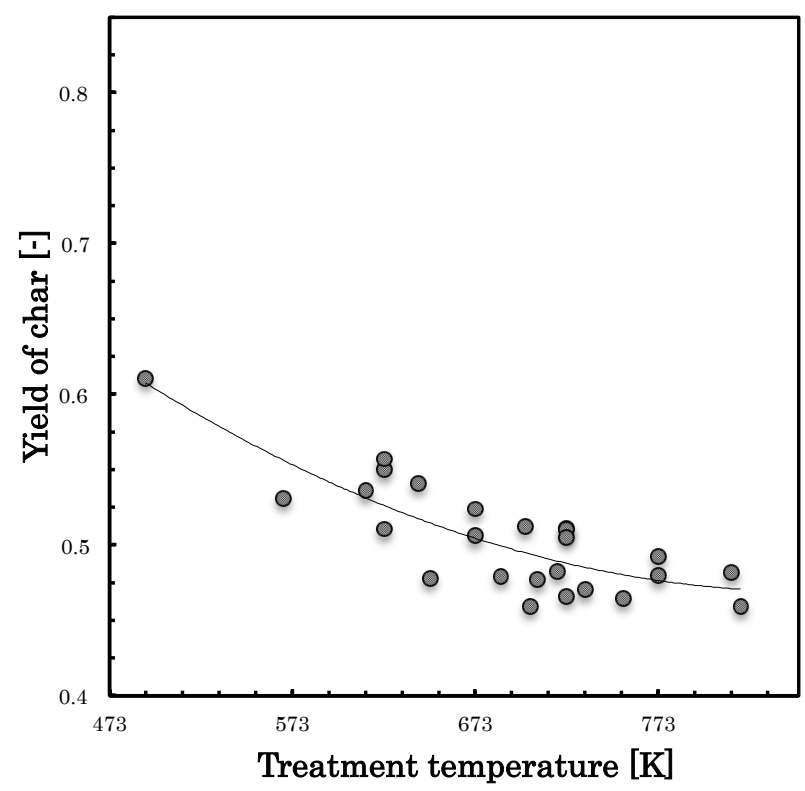

Fig.13 Yield of char carbonized in rotary kiln

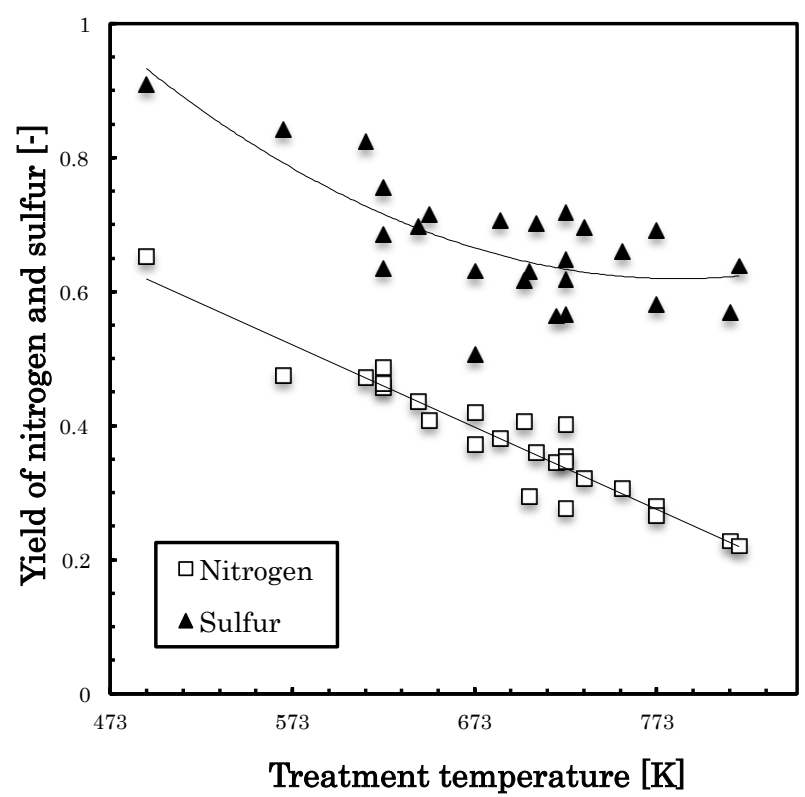

Fig.15 Yield of nitrogen and sulfur in char

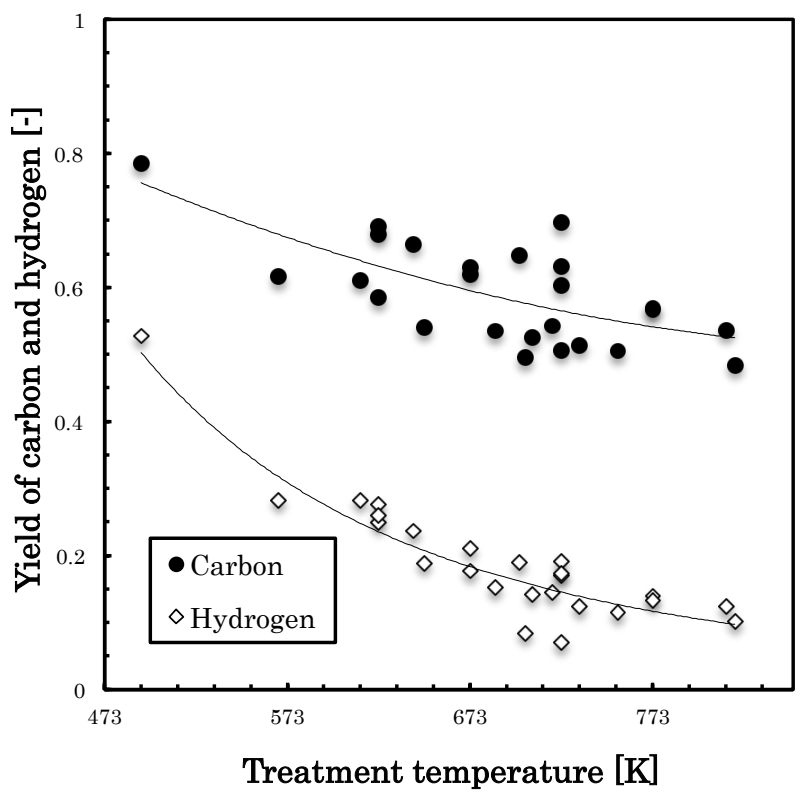

Fig.14 Yield of carbon and hydrogen in char

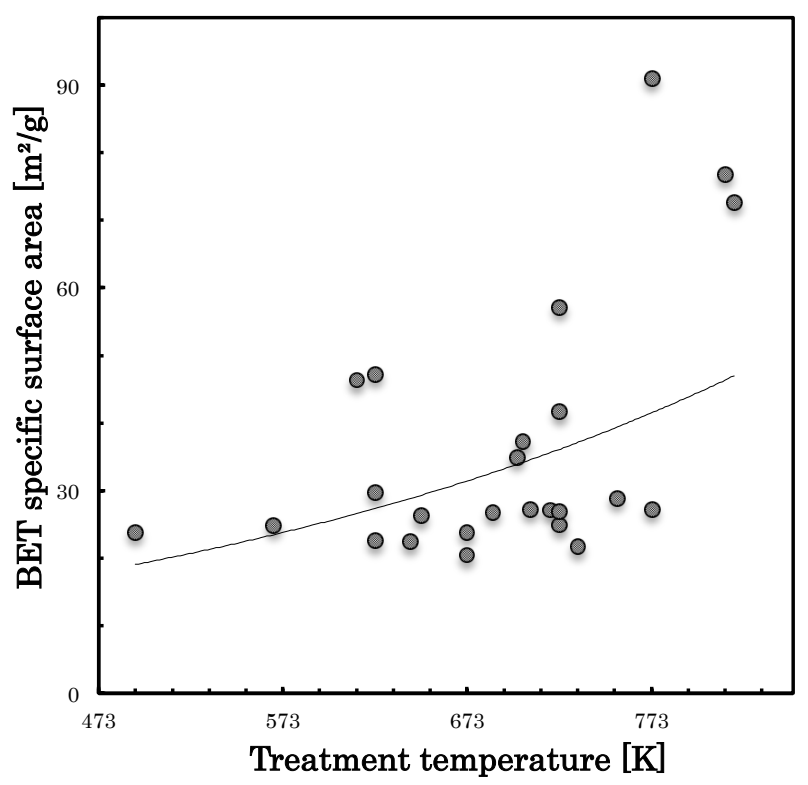

Fig.16 Comparison of BET specific surface area in both carbonizations 


\section{4. 結言}

乾燥污泥の炭化処理における窒素および硫黄挙動を把握するため，小型炭化装置およびキルンを用いた炭化実験を 実施し, 以下の知見を得た。

（1）污泥中の窒素は炭化温度が上がるとともに線形的に減少し，炭化装置による減少傾向の違いは見られなかった. また，窒素成分に対する水蒸気の影響はほとんど見られなかった。

（2）污泥中の硫黄は炭化温度が上がるとともに急激に減少寸るものの, $773 \mathrm{~K}$ 以上の炭化においては変化が小さくな った. この傾向は炭化装置によらず同じであった. 水蒸気の有無は污泥中の硫黄挙動に大きな影響を与えており， 炭化中に水蒸気を加えることで $773 \mathrm{~K}$ 以上の炭化において大幅な硫黄収率の減少が見られた.

（3）小型炭化装置とキルンにおいて，収率，窒素収率，硫黄收率，および BET 比表面積がほぼ同じ場合，いずれの 場合においても装置により炭化温度に違いが見られ，本実験においては $150-200 \mathrm{~K}$ の温度差があることがわ かった．これはキルン雰囲気温度と炉壁面温度に差があり, 実際には測定された温度より $150-200 \mathrm{~K}$ 高い温 度で炭化処理が行われたことが推測できる。

（4）小型炭化装置とキルンを用いて得られた炭化物では炭化温度に対して元素収率や BET 比表面積は類似した傾向 を示したことから，キルンを用いた堆肥化乾燥污泥の炭化においても小型炭化装置により得た知見が反映できる 可能性があることがわかった.

\section{謝辞}

本研究はNED0 省エネルギー革新技術開発事業/先導研究（2010 年 11 月～2013 年 2 月）の受託研究として行われ たものであり，ここに謝意を述べる.

\section{文献}

馬場淳一，藤田雅人，污泥の直接炭化と利用システム，環境技術，Vol. 31，No. 10 (2002)，pp. 797-801.

板谷義紀，下水污泥のアップグレード化，化学工学，Vol. 77，No. 3 (2013), pp. 175-178.

小林信介, 浜辺久, 李延亮, 板谷義紀, 上野薫, 二宮善彦, 下水污泥の堆肥化乾燥における污泥炭化物混合の影響,

化学工学論文集, Vol. 40 (2014), pp. 1-6.

小松原克展, 辻和比古, 井田四郎, $\mathrm{SO}_{2}-\mathrm{CO}_{2}-\mathrm{H}_{2} \mathrm{O}$ 混合ガスと炭素との反応, 燃料協会誌, Vol. 64, No. 5 （1985）,

pp. 339-344.

草川隆次，コークスの水蒸気に依る脱硫作用竨びに其の應用，鋳物，Vol.20，No.9-10 (1948), pp. 6-11.

牧野尚夫，佐藤幹夫，木本政義，微粉炭燃焼時の $\mathrm{NO}_{\mathrm{X}}$ ・灰中未燃分排出特性に及ぼす石炭性状の影響,

日本エネルギー学会誌, Vol.73, No.10 (1994), pp.906-913.

松永和義, 森田啓次郎, 近藤基一, 板谷勉, 森忠繁, 宍戸鴻治, 大部素宏, 有機性污泥を原料とする活性炭の製造

方法，廃棄物学会論文誌，Vol. 6, No. 3 (1995), pp. 89-94.

御友晶，小島直純，小林信介，羽多野重信，板谷義紀，森滋勝，污泥の炭化による廃棄物燃焼ガス精製用活性

コークスの製造と性能特性，化学工学論文集，Vol. 29，No. 5 (2003)， pp. 635-639.

森田啓次郎, 松永和義, 近藤基一, 板谷勉, 森忠繁, 斉藤巧, 日向博久, 各種有機性污泥からの活性炭の製法及び処 理廃液中の重金属除去，廃棄物学会論文誌，Vol. 8, No. 1 (1997), pp. 41-49.

中川浩行，人見文隆，窒素の形態変化に着目した発酲乾燥污泥の熱分解挙動，日本エネルギー学会誌，Vol.92 (2013) pp. 174-180.

中村真人, 岩㴊和則, 柚山義人, バイオマス利活用 (その 2), 農業土木学会誌, Vol. 73, No. 7 (2005), pp. 617-622.

大下和徹, 森彰宏, 高岡昌輝, 武田信生, 松本忠生, 北山憲, 下水污泥の熱分解挙動と生成物の組成・発熱量に関す 万研究，土木学会論文集，Vol. 64, No. 3 (2008)，pp. 221-230.

斎藤一郎，河村宗秀，後藤秀樹，流動層燃焼における硫黄分分別定量と $\mathrm{SO}_{2}$ ガス排出挙動，日本エネルギ一学会誌，

Vol. 82 (2003), pp. 48-56.

林石英, 小沢祥二, 松田仁樹, 架谷昌信, 謝裕生, 高温炉内脱硫反応, 日本エネルギー学会誌, Vol. 75, No.8 (1996),

pp.718-731. 
鈴木善三, 村上高広, 北島暁雄, 次世代型下水污泥焼却炉「過給式流動燃焼システム」の実用化, シンセシオロジー, Vol. 7, No. 1 (2014), pp. 27-35.

高橋輝晶, 吉田亮, 井上政義, 小柳倫生, 中野裕司, 副資材に下水污泥コンポストを用いた木材チップの堆肥化特性, 日本緑化工学会誌, Vol. 32, No.1 (2006), pp. 50-55.

鳥井昭吾, 岡島いづみ, 佐古猛, 高圧加熱水蒸気酸化による下水污泥の処理と熱エネルギー回収技術の開発, 日本エ ネルギー学会誌，Vol. 92，No. 10 (2013), pp. 945-956.

\section{References}

Baba, J. and Fujita, M., Carbonization of sludge and utilizing system, Journal of Environmental conservation engineering, Vol. 31, No. 10 (2002), pp. 797-801 (in Japanese).

Itaya, Y., Upgrading of sewage sludge, Chemical Engineering of Japan, Vol. 77, No. 3 (2013), pp. 175-178 (in Japanese).

Kobayashi, N., Hamabe, H., Yan-liang, L., Itaya, Y., Ueno, K. and Ninomiya, Y., Effect of sludge char addition on bio-drying of sludge, Kagaku Kogaku Ronbunshu, Vol. 40 (2014), pp. 1-6 (in Japanese).

Komatsubara, Y., Tsuji, K. and Ida, S., Reactivities of carbons against $\mathrm{SO}_{2}-\mathrm{CO}_{2}-\mathrm{H}_{2} \mathrm{O}$ mixture gases, Journal of the Fuel Society of Japan, Vol. 64, No. 5 (1985), pp. 339-344 (in Japanese).

Kusakawa, K., Desulfrization and application of coke with steam, Journal of Japan Foundary Engineering Society, Vol. 20, No. 9-10 (1948), pp. 6-11 (in Japanese).

Makino, H., Sato, M. and Kimoto, M., Influence of Coal properties on emission characteristics of $\mathrm{NO}_{\mathrm{x}}$ and unburned carbon in fly ash in pulverized coal combustion, Journal of the Japan Institute of Energy, Vol. 73, No.10 (1994), pp.906-913 (in Japanese).

Matsunaga, K., Morita, K., Kondoh, M., Itatani, T., Mori, T., Shishido, K. and Ohbu, M., Method for producing high adsorptive activated charcoal from organic sludge, Journal of the Japan Society of Waste Management Experts, Vol. 6, No. 3 (1995), pp. 89-94 (in Japanese).

Mitomo, A., Kojima, N., Kobayashi, N., Hatano, S., Itaya, Y. and Mori, S., Production and performance of active cokes by carbonization of sludge for removal of pollutants in combustion gas of wastes, Kagaku Kogaku Ronbunshu, Vol. 29, No. 5 (2003), pp. 635-639 (in Japanese).

Morita, K., Matsunaga, K., Motoichi, K., Itadani, T., Mori, T., Saitoh, T. and Hinata, H., Method for producing high-quality activated carbon from organic waste sludges and for the removal of heavy metals in waste water after chemical treatment, Journal of the Japan Society of Waste Management Experts, Vol. 8, No. 1 (1997), pp. 41-49 (in Japanese).

Nakagawa, H. and Hitomi, F., Pyrolysis behavior of biologically dried sewage sludge : change in nitrogen form during heat treatment, Journal of the Japan Institute of Energy, Vol. 92 (2013), pp. 174-180 (in Japanese).

Nakamura, M., Iwabuchi, K. and Yuyama, Y., Toward the holistic use of biomass resources (2), Journal of the Agricultural Engineering Society, Japan, Vol. 73, No. 7 (2005), pp. 617-622 (in Japanese).

Oshita, K., Mori, A., Takaoka, M., Takeda, N., Matsumoto, T. and Kitayama, A., Fundamental study on the composition and heating value of char, tar and gas from sewage sludge pyrolysis, Japan Society of Civil Engineers, Vol. 64, No. 3 (2008), pp. 221-230 (in Japanese).

Saito, I., Kawamura, M. and Goto, H., Sulfur from in coal and emission behavior at AFBC plant, Journal of the Japan Institute of Energy, Vol. 82 (2003), pp. 48-56 (in Japanese).

Shi-Ying, L., Ozawa, S., Matsuda, H., Hasatani, M. and Yu-Seng, X., Chemical reactions of injection desulfurization, Journal of the Japan Institute of Energy, Vol. 75, No.8 (1996), pp.718-731 (in Japanese).

Suzuki, Y., Murakami, T. and Kitajima, A., Practical use of an advanced sewage sludge oncinerator, turbocharged fluidized bed incinerator, Synthesiology, Vol. 7, No. 1 (2014), pp. 27-35 (in Japanese).

Takahashi, T., Yoshida, A., Inoue, M., Oyanagi, M. and Nakano, Y., The characteristics of wood chip composting mixed with sewage sludge compost as submaterial, Journal of the Japan Society of Revegetation Technology, Vol. 32, No. 1 (2006), pp. 50-55 (in Japanese).

Torii, S., Okajima, I. and Sako, T., Treatment and energy recovery of sewage sludge by high-pressure superheated steam oxidation, Journal of the Japan Institute of Energy, Vol. 92, No. 10 (2013), pp. 945-956 (in Japanese). 